\title{
PENGOLAHAN MIE YANG DIFORTIFIKASI DENGAN IKAN DAN RUMPUT LAUT SEBAGAI SUMBER PROTEIN, SERAT KASAR, DAN IODIUM
}

\begin{abstract}
Murniyati*), Subaryono*), dan (rma Hermana*)
ABSTRAK

Penelitian pembuatan mie ikan-rumput laut telah dilakukan dengan tujuan untuk mendapatkan formulasi pembuatan mie yang kaya akan protein, serat, dan iodium. Bahan formulasi yang digunakan adalah ikan swangi/mata goyang (Priacanthus tayenus) dan rumput laut (Eucheuma cottonii). Variasi perlakuan yang digunakan adalah jumlah penambahan daging ikan $(20,30$, dan $40 \%$ ) dan rumput laut $(10,20,30$, dan 40\%). Pengamatan yang dilakukan meliputi organoleptik (kenampakan, warna, aroma, rasa, dan tekstur) menggunakan skala hedonik dan uji kimiawi (kadar air, abu, protein, lemak, serat kasar, dan kadar iodium). Hasil penelitian menunjukkan bahwa perlakuan yang terbaik adalah mie dengan penambahan ikan $30 \%$ dan rumput laut $20 \%$. Produk akhir mie ikan-rumput laut kering mengandung protein 16,64\%; kadar air 9,04\%; kadar serat kasar sebanyak 0,20\%; dan kadar iodium 6,29 ppm.
\end{abstract}

ABSTRACT: Processing of noodles fortified with fish and seaweed as a source of protein, crude fiber and iodine. By: Murniyati, Subaryono and Irma Hermana

Research on processing of noodle fortified with fish and seaweed as a source of protein, fiber and iodine has been conducted. The fortification materials used in this research were swangi fish (Priacanthus tayenus) and seaweed (Eucheuma cottonii). Treatments consisted of addition of fish (20,30 and 40\%) and seaweed (10,20, 30 and 40\%). Observation was done on organoleptic characteristics (appearance, color, aroma, taste and texture) using hedonic scale and chemical test (water, ash, protein, fat, crude fiber and iodine contents). Results showed that the best treatment was noodles with the addition of $30 \%$ fish and $20 \%$ seaweed. The protein, moisture, crude fiber, and iodine contents of dried fish-seaweed noodles were approximately $16.64 \%, 9.04 \%, 0.20 \%$ and 6.29 ppm respectivelly.

KEYWORDS: Eucheuma cottonii, Priacanthus tayenus, noodles, iodine, crude fiber

\section{PENDAHULUAN}

Mie merupakan produk makanan yang sangat populer dan banyak dikonsumsi oleh masyarakat Indonesia. Konsumsi mie di Indonesia tercatat sebagai yang terbesar kedua di dunia setelah RRC. Meskipun demikian, mie bukanlah merupakan makanan yang dianggap istimewa, hal ini terjadi karena umumnya kandungan gizi produk mie dan olahannya masih sangat rendah, terutama kandungan proteinnya (Anon., 2008b). Penambahan ikan sebagai bahan campuran membuat mie sangat prospektif untuk dikembangkan, mengingat ikan adalah salah satu bahan makanan yang murah, banyak disukai oleh masyarakat Indonesia, memiliki citarasa yang khas, tersedia melimpah dan kandungan gizinya relatif tinggi. Ikan swangi (Priacanthus tayenus) atau ikan mata besar/mata goyang merupakan salah satu ikan yang mempunyai daging berwarna putih dan harganya murah. Produksi ikan jenis ini meningkat terus, pada tahun 2005 total produksinya sebanyak 16.440 ton, sedangkan pada tahun 2008 menjadi 20.549 ton (Anon., 2009), atau kenaikan rata-rata dari tahun 20052008 sebesar $24,99 \%$.

Kandungan gizi rumput laut yang terpenting adalah trace element, khususnya iodium yang berkisar 0,1$0,15 \%$ dari bobot keringnya serta kandungan seratnya yang tinggi. Kandungan iodium rumput laut sekitar 2.400 sampai 155.000 kali lebih banyak dibandingkan kandungan iodium dalam sayur-sayuran yang tumbuh di daratan. Penambahan rumput laut Eucheuma cottonii sebanyak $37 \%$ ke dalam bahan dasar mie basah, mie instan, dan mie kering, dapat meningkatkan total serat pangan hingga $29,7 \%$ bobot kering (mie basah), 18,2\% bobot kering (mie instan), dan $18,8 \%$ bobot kering (mie kering). Penambahan rumput laut 37\% meningkatkan 5,2 ppm bobot kering iodium dalam mie basah; 5,5 ppm bobot kering iodium

Peneliti pada Balai besar Riset Pengolahan Produk dan Bioteknologi Kelautan dan Perikanan;

E-mail: moerniyati@gmail.com 
dalam mie instan; dan 6 ppm bobot kering iodium mie kering (Suryaalamsah, 2007). E. cottonii digunakan karena mudah diperoleh dan harganya relatif murah.

Tujuan dari penelitian ini adalah untuk mendapatkan formulasi pembuatan mie dengan penambahan ikan dan rumput laut sebagai sumber protein, serat kasar, dan iodium untuk meningkatkan nilai gizi mie.

\section{BAHAN DAN METODE}

\section{Bahan}

Bahan baku utama yang digunakan dalam pembuatan mie adalah tepung terigu, daging ikan swangi ( $P$. tayenus), dan rumput laut ( $E$. cottonii). Selain bahan baku utama, digunakan bahan tambahan yaitu telur, air, garam, dan soda kue, sedangkan peralatan yang digunakan adalah alat pencetak dan pemotong mie, baskom /wadah plastik, panci, kompor, ayakan, pisau, dan talenan. Rumput laut yang digunakan dalam bentuk segar. Formulasi dasar bahan-bahan pembuat mie adalah sebagai berikut:

$\begin{array}{lll}\text { Terigu } & : 100 & \mathrm{~g} \\ \text { Air } & : 26 & \mathrm{~g} \\ \text { Telur } & : 15 & \mathrm{~g} \\ \text { Garam } & : 2,0 & \mathrm{~g} \\ \text { MSG } & : 1,5 & \mathrm{~g} \\ \text { Tepung tapioka } & : 1,4 & \mathrm{~g} \\ \text { Soda kue } & : 0,5 & \mathrm{~g}\end{array}$

Perlakuan yang diuji dalam formulasi mie ikanrumput laut adalah jumlah penambahan daging ikan dan rumput laut sebagai berikut:

a. Daging ikan: 20,30 , dan $40 \%$

b. Rumput laut: $10,20,30$, dan $40 \%$

Masing-masing adalah persentase terhadap tepung terigu yang digunakan dalam formula.

\section{Metode}

Ikan swangi diperoleh dari hasil tangkapan nelayan di Muarabaru, selanjutnya dibawa ke laboratorium BBRP2B menggunakan es dalam coolbox. Ikan dicuci

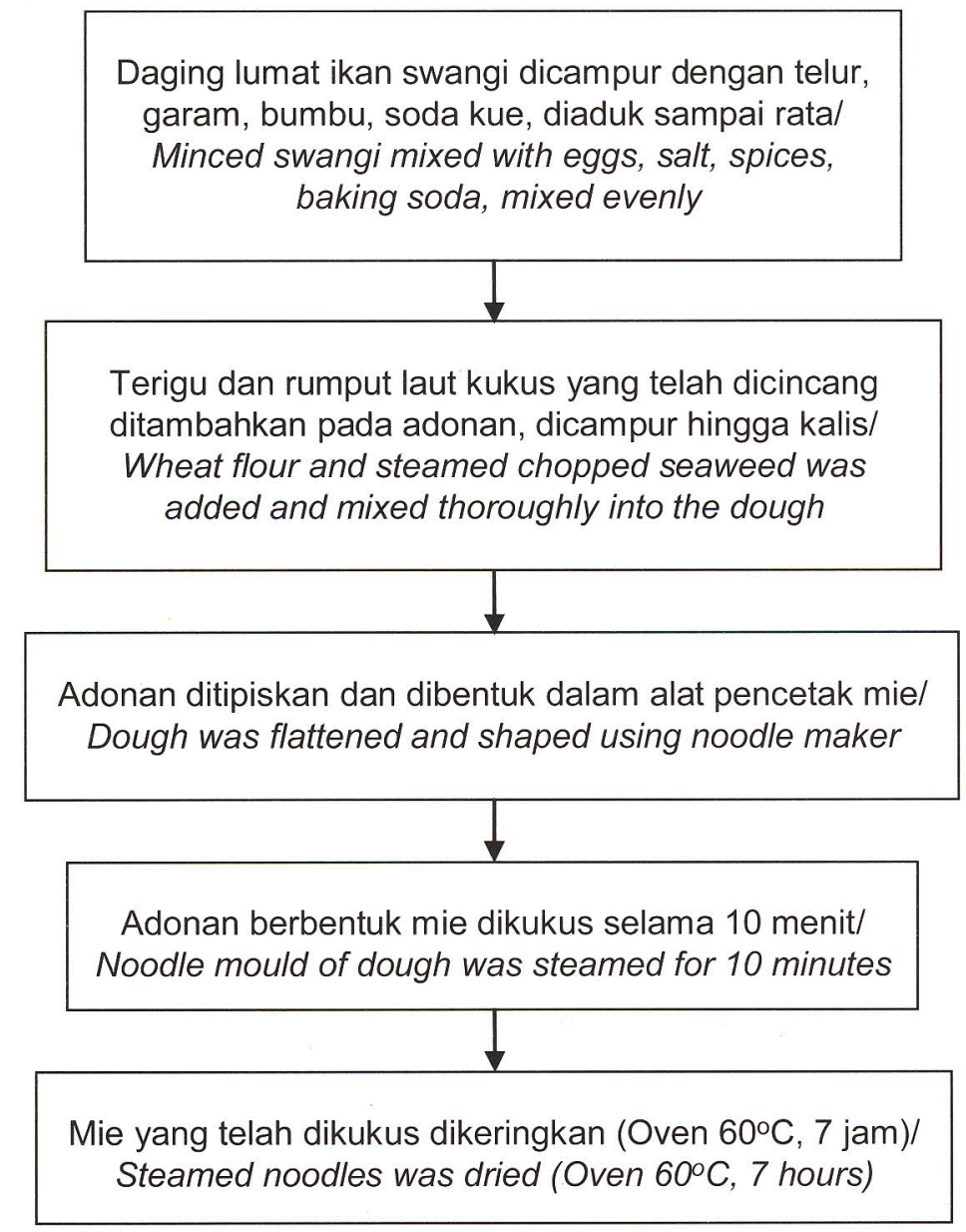

Gambar 1. Diagram alir proses pembuatan mie ikan-rumput laut. Figure 1. Flow chart of fish-seaweed noodle processing. 
bersih, diambil dagingnya, dan digiling sampai halus (lumat). Rumput laut yang digunakan berasal dari Pulau Panjang hasil budidaya rakyat yang telah mengalami proses pengeringan dan pemutihan, direndam dalam air tawar selama satu malam. Daging ikan yang telah dilumatkan dicampur dengan garam, telur, bumbubumbu, dan soda kue. Selanjutnya dicampurkan terigu dan rumput laut yang sudah dikukus selama 10 menit dan dicincang halus serta dibuat adonan yang lumat dan liat. Adonan ditipiskan dengan alat pencetak mie untuk dibuat lembaran setebal $2 \mathrm{~mm}$ dan dipotong memanjang dengan cetakan mie untuk kemudian dikukus selama 10 menit (Gambar 1). Selanjutnya mie dikeringkan di dalam oven dengan suhu $60^{\circ} \mathrm{C}$ selama 7 jam (Anon., 2008a).

\section{Parameter yang Diamati}

\section{Organoleptik}

Penilaian organoleptik produk mie ikan-rumput laut dilakukan dengan menggunakan lembar penilaian skala hedonik terhadap parameter kenampakan, warna, aroma, rasa, dan tekstur dengan skor 1-9 (9 sangat disukai dan 1 sangat tidak disukai).

\section{Kimiawi}

Uji kimiawi yang dilakukan meliputi kadar air, abu, lemak, protein, serat kasar, dan kadar iodium. Uji kimiawi kadar air menggunakan metode gravimetri (AOAC, 2000), protein dengan metode Kjeldahl, serat kasar dengan metode SNI 01-2891-1992 (BSN, 1992) dan iodium dengan Spektrofotometri (Riyanto, 2004).

\section{HASIL DAN BAHASAN}

\section{Parameter Organoleptik}

\section{Kenampakan}

Pada Gambar 2 dapat dilihat bahwa nilai organoleptik kenampakan terendah terdapat pada perlakuan penambahan ikan $30 \%$ dan rumput laut 10\% yaitu sebesar 3,18 dan tertinggi pada perlakuan penambahan ikan $30 \%$ dan rumput laut $20 \%$ sebesar 6,08 . Kenampakan dari mie dengan penambahan ikan dan rumput laut terlihat bersih, menarik, bentuk seragam, dan cerah. Hasil analisis statistik mie ikanrumput laut menunjukkan bahwa perlakuan penambahan ikan dan rumput laut berpengaruh terhadap nilai organoleptik kenampakan $(p<0,05)$.

\section{Warna}

Pada Gambar 3 dapat dilihat bahwa nilai organoleptik warna terendah terdapat pada perlakuan penambahan ikan $30 \%$ dan rumput laut $10 \%$ yaitu sebesar 3,47 dan tertinggi pada perlakuan penambahan ikan $30 \%$ dan rumput laut $20 \%$ sebesar 6,40 . Mie ikan berwarna kuning keputihan cerah, cukup cemerlang dan warnanya merata. Menurut Tobias et al. (2005) secara kuantitatif, penambahan rumput laut dapat mempengaruhi warna.

Menurut Winarno (1992), uji warna lebih banyak melibatkan indra penglihatan dan merupakan salah satu indikator untuk menentukan apakah suatu bahan

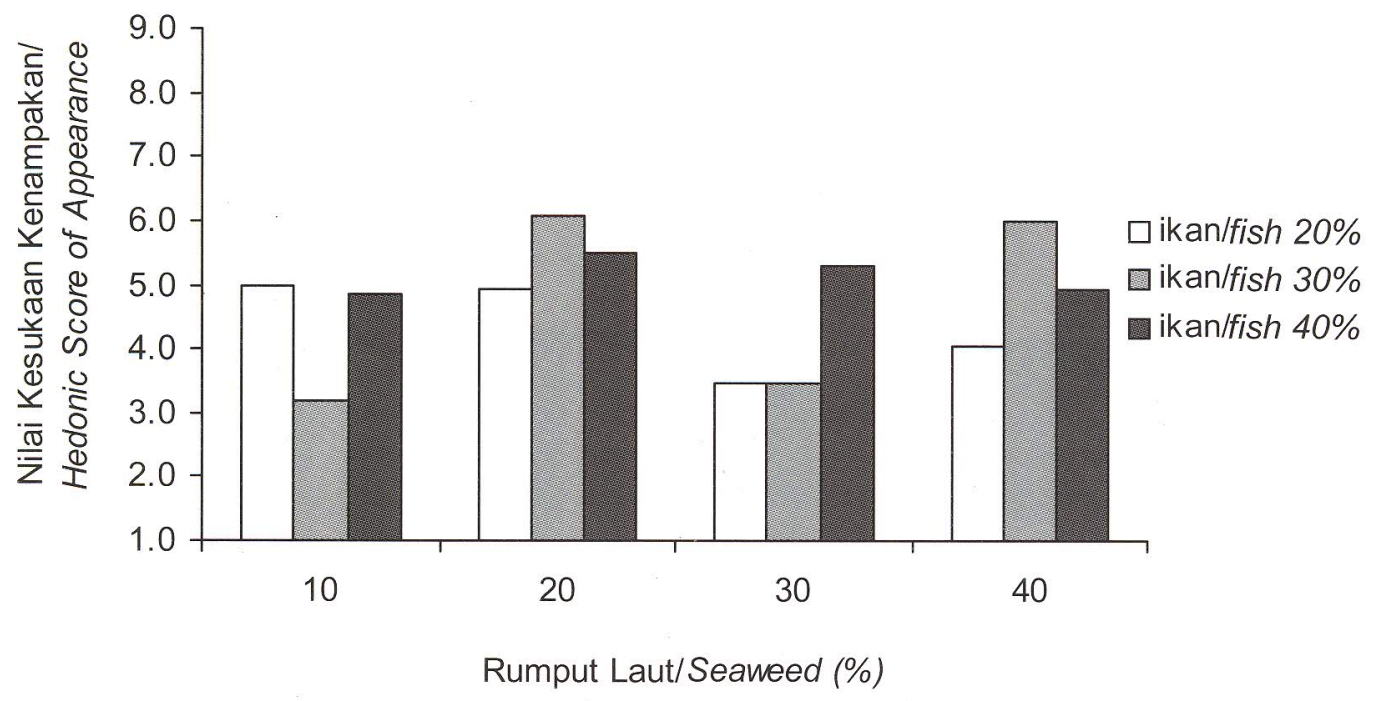

Gambar 2. Nilai kesukaan kenampakan mie ikan-rumput laut dari beberapa perlakuan Figure 2. Hedonic score of appearance of fish-seaweed noodle from various treatments. 


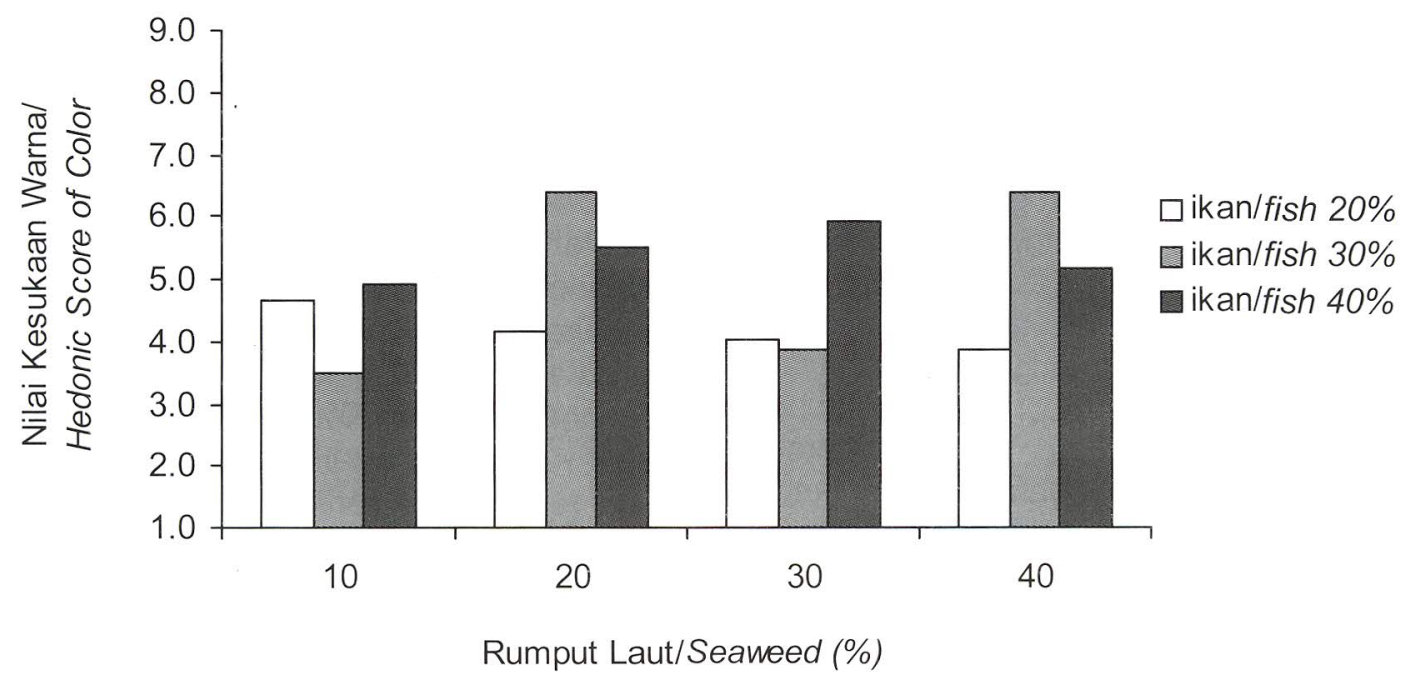

Gambar 3. Nilai kesukaan warna mie ikan-rumput laut dari beberapa perlakuan. Figure 3. Hedonic score of color of fish-seaweed noodle from various treatments.

pangan diterima atau tidak oleh masyarakat konsumen.

Makanan yang berkualitas (rasanya enak, bergizi, dan bertekstur baik) belum tentu disukai oleh konsumen bila bahan pangan tersebut memiliki warna yang tidak sedap dipandang atau menyimpang dari warna aslinya. Hasil analisis statistik mie ikan-rumput laut menunjukkan bahwa perlakuan penambahan ikan dan rumput laut berpengaruh terhadap nilai organoleptik warna $(p<0,05)$.

\section{Aroma}

Pada Gambar 4 dapat dilihat bahwa nilai organoleptik aroma terendah terdapat pada perlakuan penambahan ikan $20 \%$ dan rumput laut $20 \%$ yaitu sebesar 4,96 dan tertinggi pada perlakuan penambahan ikan $30 \%$ dan rumput laut $20 \%$ sebesar 5,88 .

Hasil penilaian panelis terhadap aroma mie ikanrumput laut menunjukkan bahwa perlakuan kombinasi ikan 30\% dan rumput laut 20\% merupakan perlakuan yang paling disukai dan perlakuan kombinasi ikan $20 \%$ dan rumput laut $20 \%$ merupakan perlakuan yang paling tidak disukai. Aroma mie ikan tersebut cukup gurih, aroma atau bau ikan kurang tercium dan tidak ada aroma tambahan yang mengganggu. Menurut Winarno (1992), uji aroma lebih banyak melibatkan indra penciuman, karena kelezatan suatu makanan sangat ditentukan oleh aroma makanan tersebut dan

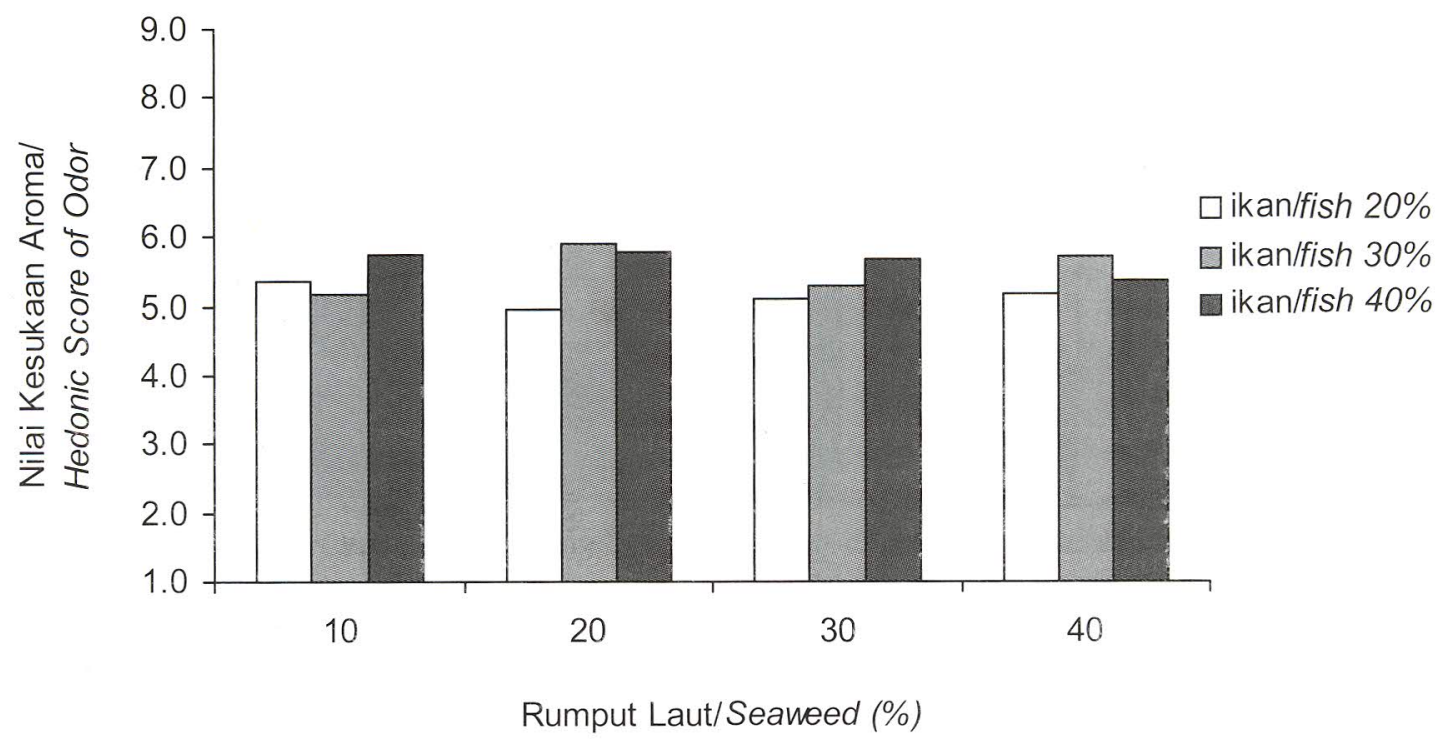

Gambar 4. Nilai kesukaan aroma mie ikan-rumput laut dari beberapa perlakuan. Figure 4. Hedonic score of odor of fish-seaweed noodle from various treatments. 
merupakan salah satu indikator penting dalam menentukan kualitas bahan pangan. Umumnya konsumen akan menyukai bahan pangan jika mempunyai aroma khas yang tidak menyimpang dari aroma normal. Hasil analisis statistik mie ikan-rumput laut menunjukkan bahwa perlakuan penambahan ikan berpengaruh terhadap nilai organoleptik aroma $(p<0,05)$ sedangkan penambahan rumput laut tidak berpengaruh.

\section{Rasa}

Pada Gambar 5 dapat dilihat bahwa nilai organoleptik rasa terendah terdapat pada perlakuan penambahan ikan $40 \%$ dan rumput laut $30 \%$ yaitu sebesar 2,95 dan tertinggi pada perlakuan penambahan ikan $30 \%$ dan rumput laut $10 \%$ sebesar 5,62. Rasa mie ikan-rumput laut cukup gurih, tidak ada rasa tambahan, untuk mie dengan penambahan ikan $40 \%$ terasa gurih.

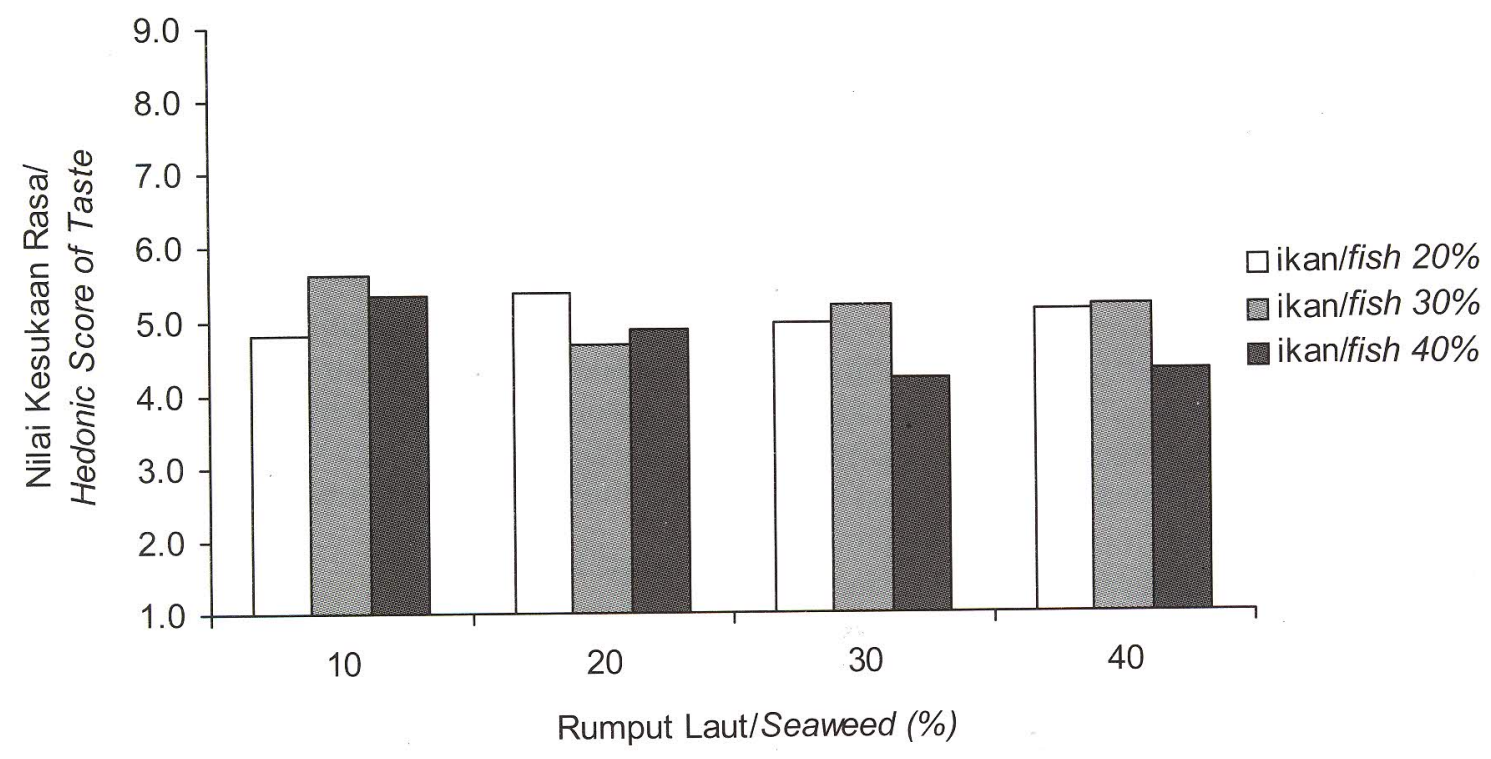

Gambar 5. Nilai kesukaan rasa mie ikan-rumput laut dari beberapa perlakuan.

Figure 5. Hedonic score of taste of fish-seaweed noodle from various treatments.

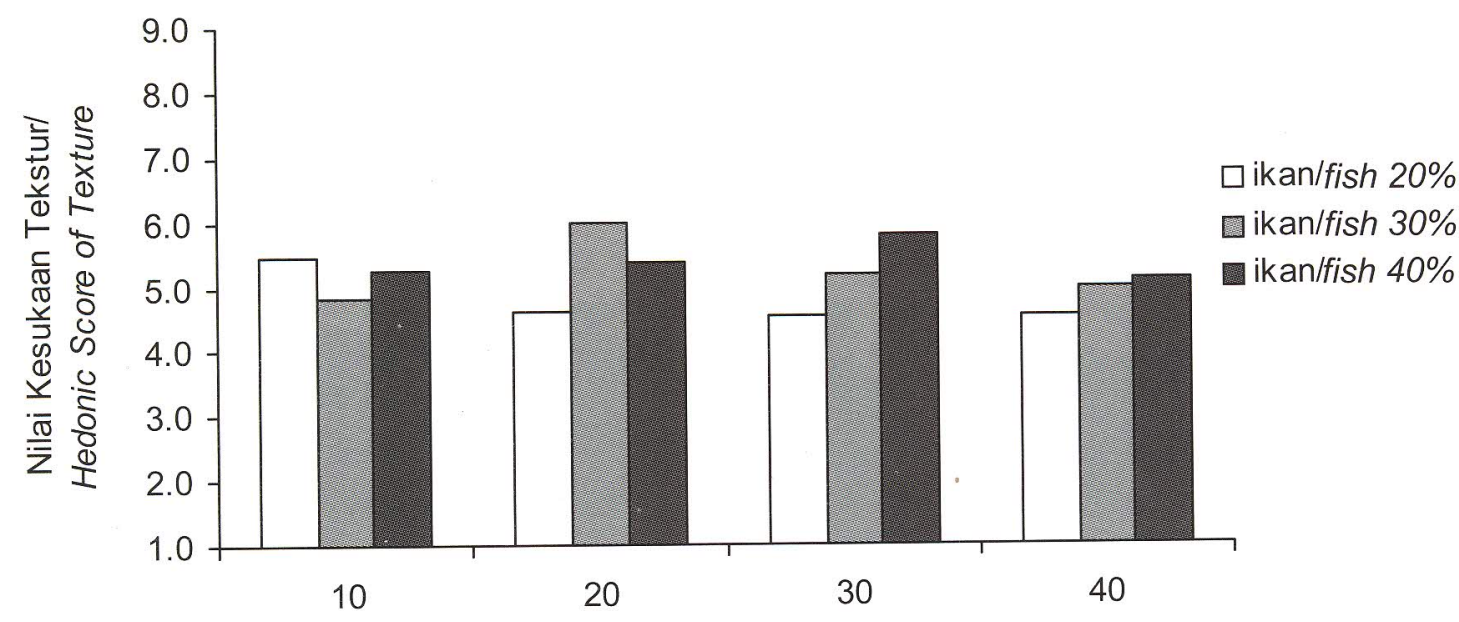

Rumput Laut/Seaweed (\%)

Gambar 6. Nilai kesukaan tekstur mie ikan-rumput laut dari beberapa perlakuan. Figure 6. Hedonic score of texture of fish-seaweed noodle from various treatments. 
Hasil analisis statistik mie ikan-rumput laut menunjukkan bahwa perlakuan penambahan ikan dan rumput laut tidak berpengaruh terhadap nilai organoleptik rasa $(p>0,05)$.

\section{Tekstur}

Pada Gambar 6 dapat dilihat bahwa nilai organoleptik tekstur terendah terdapat pada perlakuan penambahan ikan $20 \%$ dan rumput laut $40 \%$ yaitu sebesar 4,39 dan tertinggi pada perlakuan penambahan ikan 30\% dan rumput laut 20\% sebesar 6,39 . Hal ini menunjukkan bahwa mie ikan-rumput laut yang dihasilkan masuk dalam kategori agak suka hingga suka. Tekstur mie ikan-rumput laut kering, renyah dan tidak liat. Penambahan rumput laut dapat mempengaruhi tekstur pada mie dengan mutu yang bagus (Tobias et al., 2005).

Gambar 6 memperlihatkan perlakuan kombinasi ikan $30 \%$ dan rumput laut $20 \%$ adalah perlakuan dengan tekstur yang paling disukai. Menurut Chang \& Wu (2008), penambahan telur dengan rumput laut pada mie akan meningkatkan mutu tekstur dari produk akhir mie. Tekstur yang liat diperoleh apabila dalam pembuatan mie menggunakan tepung terigu yang mengandung protein tinggi yaitu sekitar $11 \%-13 \%$ atau bahkan lebih. Hal ini terjadi karena tepung terigu berprotein tinggi yang bercampur dengan bahan cair, glutennya akan mengembang dan saling mengikat dengan kuat (Anon., 2007). Hasil analisis statistik mie ikan-rumput laut menunjukkan bahwa perlakuan penambahan ikan berpengaruh terhadap nilai organoleptik tekstur $(p<0,05)$ sedangkan penambahan rumput laut tidak berpengaruh.

\section{Parameter Kimiawi}

\section{Kadar air}

Pada Gambar 7 dapat dilihat bahwa kadar air terendah terdapat pada perlakuan mie dengan penambahan ikan $30 \%$ dan rumput laut $20 \%$ yaitu sebesar $9,04 \%$ dan tertinggi pada perlakuan mie dengan penambahan ikan $20 \%$ dan rumput laut $40 \%$ sebesar $10,75 \%$. Hasil analisis mie tanpa ikan dan rumput laut (kontrol) mempunyai kadar air sebesar $8,34 \%$. Kadar air maksimum yang diijinkan menurut SNI untuk mie kering adalah $8 \%$ untuk mutu I dan $10 \%$ untuk mutu II (BSN, 2000). Dari pengamatan organoleptik diperoleh bahwa mie dengan penambahan ikan $30 \%$ dan rumput laut $20 \%$ lebih kering dibandingkan dengan perlakuan lainnya.

Hasil analisis statistik untuk kadar air menunjukkan bahwa perlakuan penambahan ikan dan rumput laut berpengaruh sangat nyata terhadap kadar air $(p<0,05)$. Semakin tinggi konsentrasi penambahan rumput laut cenderung meningkatkan kadar air.

\section{Kadar abu}

Pada Gambar 8 dapat dilihat bahwa kadar abu terendah terdapat pada perlakuan mie dengan penambahan ikan $40 \%$ dan rumput laut $30 \%$ yaitu sebanyak $3,0 \%$ dan tertinggi pada perlakuan mie dengan penambahan ikan 30\%, rumput laut 10\% sebanyak 3,29\%. Kadar abu yang dijinkan menurut SNI untuk mie kering adalah maksimum 3\% (BSN, 1992). Dari Gambar tersebut dapat dilihat bahwa semakin tinggi penambahan rumput laut dan ikan maka kadar abu semakin rendah.

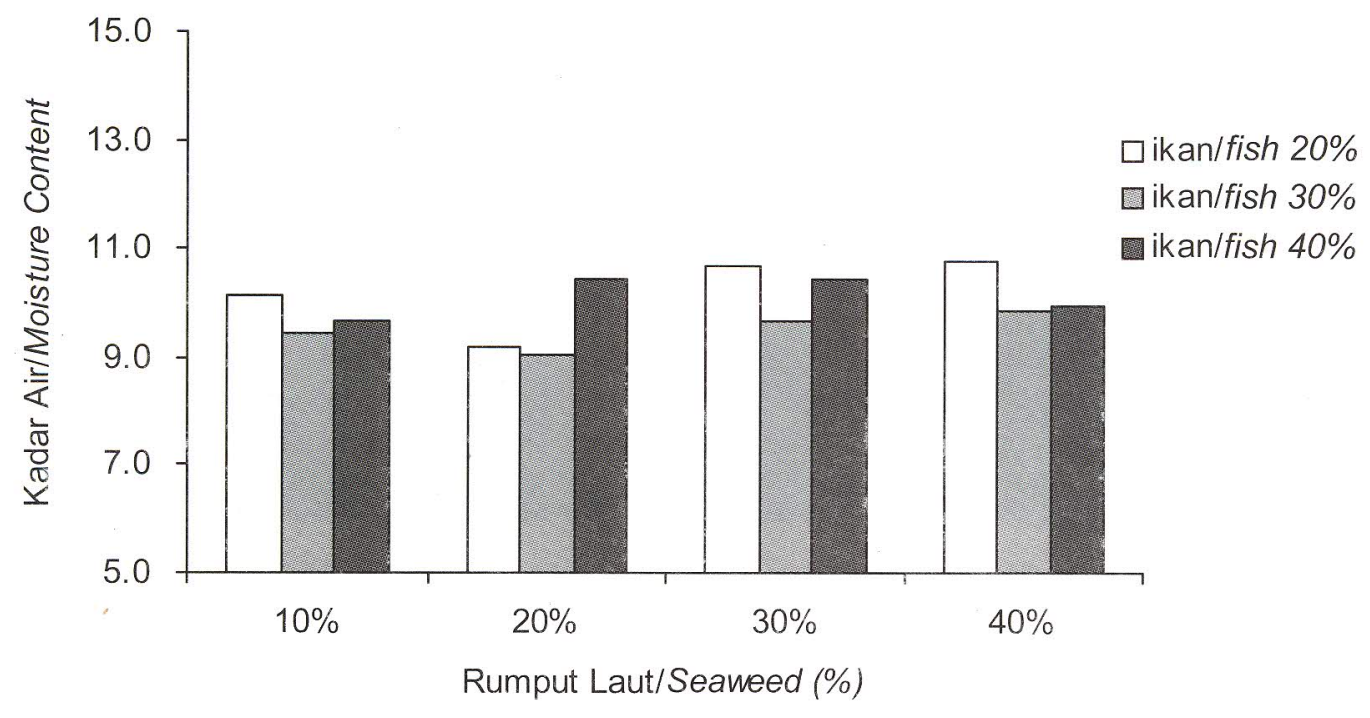

Gambar 7. Kadar air mie ikan-rumput laut dari beberapa perlakuan.

Figure 7. Moisture content of fish-seaweed noodle from various treatments. 


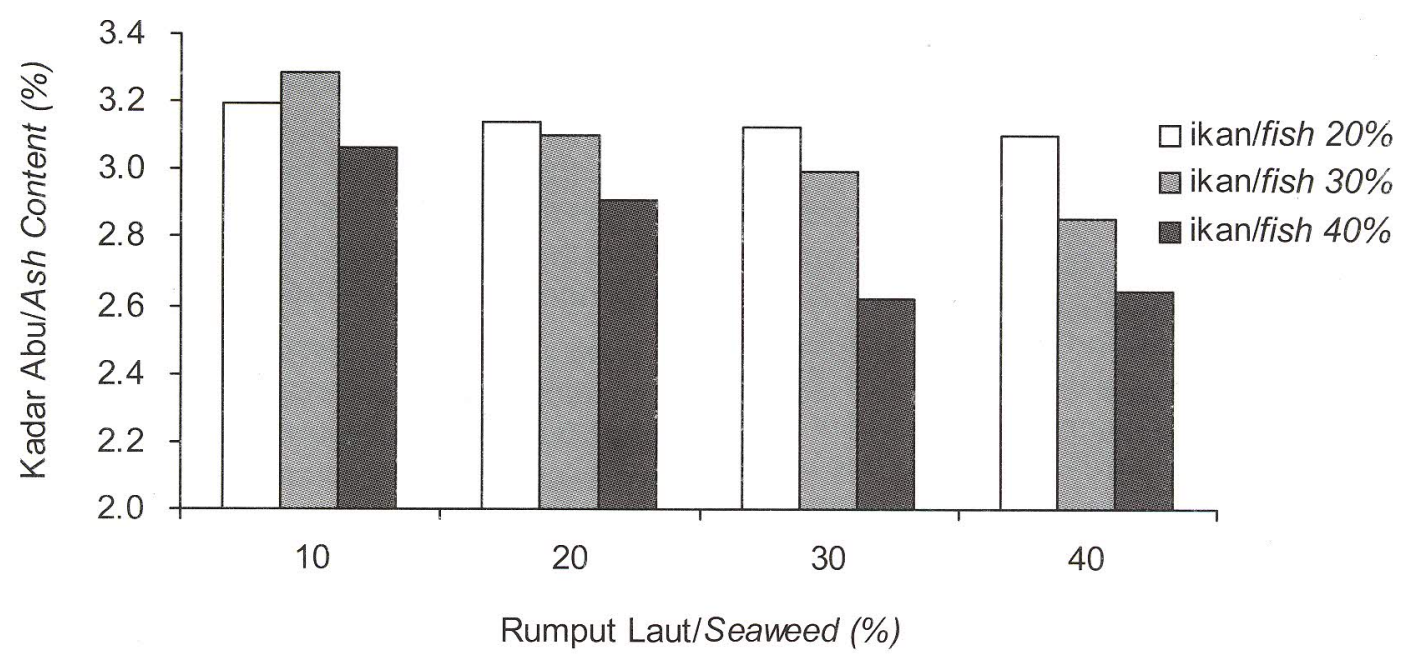

Gambar 8. Kadar abu mie ikan-rumput laut dari beberapa perlakuan Figure 8. Ash content of fish-seaweed noodle from various treatments

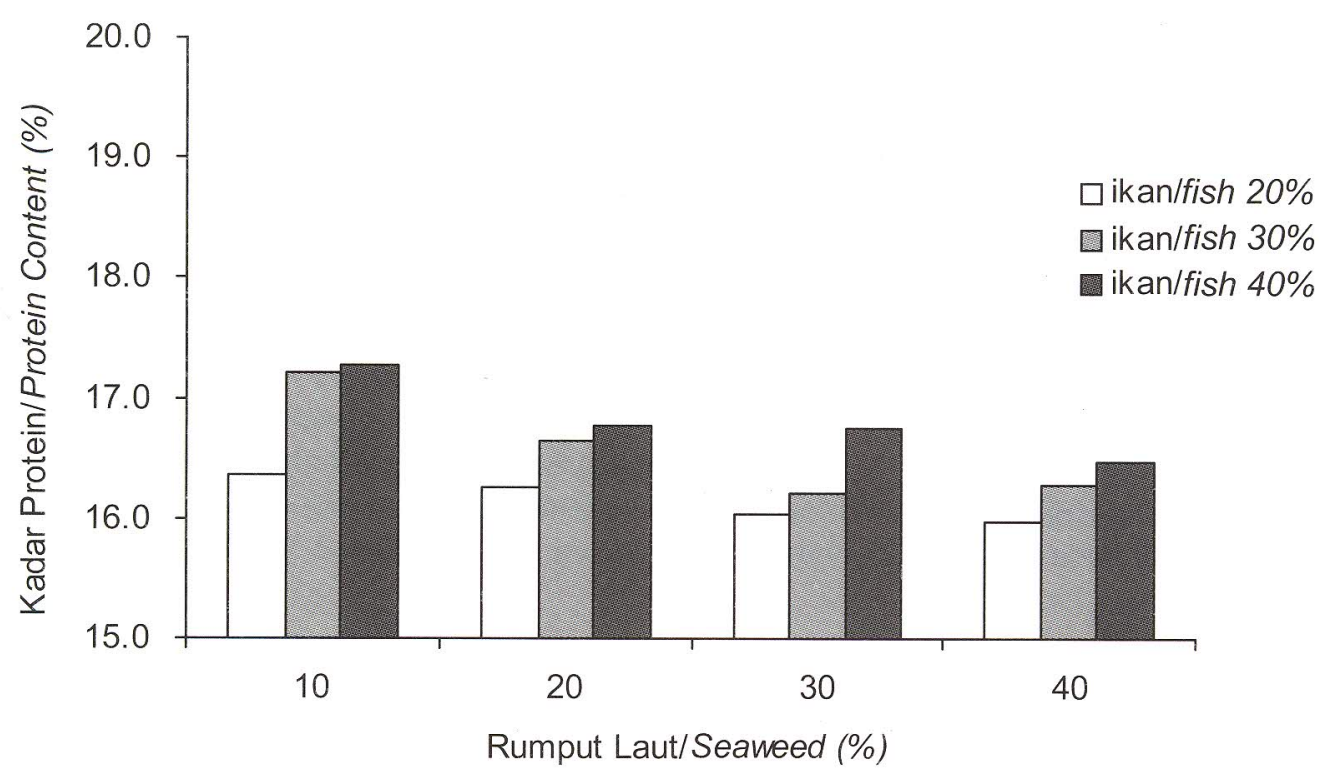

Gambar 9. Kadar protein mie ikan-rumput laut dari beberapa perlakuan.

Figure 9. Protein content of fish-seaweed noodle from various treatments.

Hasil analisis statistik kadar abu mie ikan-rumput laut menunjukkan bahwa perlakuan penambahan rumput laut dan ikan berpengaruh nyata terhadap kadar abu produk mie yang dihasilkan $(p<0,05)$.

\section{Protein}

Pada Gambar 9 dapat dilihat bahwa kadar protein terendah terdapat pada perlakuan penambahan ikan $20 \%$ dan rumput laut $40 \%$ yaitu sebesar $16,03 \%$ dan tertinggi pada perlakuan penambahan ikan $40 \%$ dan rumput laut $10 \%$ sebesar $17,26 \%$, sedangkan hasil analisis mie tanpa ikan dan rumput laut (kontrol) mempunyai kadar protein sebesar 9,07\%. Kadar protein untuk mie kering yang diijinkan menurut SNI adalah minimum $11 \%$ untuk mutu I dan $8 \%$ untuk mutu II (BSN, 1992; BSN, 2000). Hasil analisis statistik mie ikan-rumput laut menunjukkan bahwa perlakuan penambahan ikan dan rumput laut berpengaruh terhadap kadar protein $(p<0,05)$.

Kandungan protein utama tepung terigu yang berperan dalam pembuatan mie adalah gluten. Gluten dapat dibentuk dari gliadin (prolamin dalam gandum) dan glutenin. Protein dalam tepung terigu untuk pembuatan mie harus dalam jumlah yang cukup tinggi 
supaya mie menjadi elastis dan tahan terhadap penarikan sewaktu proses produksinya (Anon., 2008a). Jenis tepung terigu yang digunakan untuk mie sebaiknya dari jenis tepung terigu berprotein sedang (10-11\%) sampai dengan jenis tepung yang berprotein tinggi (12-13\%) (Anon., 2007). Pada pembuatan mie dengan jenis tepung terigu protein sedang, proses pengadukan dan rolling-nya tidak selama dan sebanyak yang diperlukan jika menggunakan tepung terigu protein tinggi. Menurut Irianto \& Soesilo (2007), daging ikan lumat yang ditambahkan sebesar 20\% pada pembuatan mie kering dan $25 \%$ pada mie basah dapat meningkatkan kadar protein masing-masing dar $5,9 \%$ menjadi $11,9 \%$ dan dari $5,1 \%$ menjadi $7,4 \%$

\section{Kadar lemak}

Pada Gambar 10 dapat dilihat bahwa kadar lemak terendah terdapat pada perlakuan penambahan ikan $20 \%$ dan rumput laut $30 \%$ yaitu sebesar $0,46 \%$ dan tertinggi pada perlakuan penambahan ikan $40 \%$ dan rumput laut $40 \%$ sebesar $1,02 \%$, sedangkan hasil analisis mie tanpa ikan dan rumput laut (kontrol) mempunyai kadar lemak sebesar $2,10 \%$.

Dari gambar tersebut terlihat bahwa semakin banyak ikan dan rumput laut yang ditambahkan semakin besar kadar lemaknya. Hasil analisis statistik mie ikan-rumput laut menunjukkan bahwa perlakuan penambahan ikan dan rumput laut berpengaruh terhadap kadar lemaknya $(p<0,05)$.

\section{Kadar serat kasar}

Pada Gambar 11 dapat dilihat bahwa kadar serat kasar terendah terdapat pada perlakuan penambahan ikan 30\% dan rumput laut 20\% yaitu sebanyak 0,20\% dan tertinggi pada perlakuan penambahan ikan $20 \%$ dan rumput laut $40 \%$ sebanyak $0,77 \%$, sedangkan hasil analisis mie tanpa ikan dan rumput laut (kontrol) mempunyai kadar serat kasar sebesar 0,35\%. Hasil analisis statistik mie ikan-rumput laut menunjukkan bahwa perlakuan penambahan rumput laut dan ikan berpengaruh terhadap kadar serat kasar $(p<0,05)$.

Menurut Garrow \& James (1993), kebutuhan serat untuk tubuh manusia sangat bervariasi menurut pola makan dan tidak ada anjuran kebutuhan sehari secara khusus untuk serat makanan. Konsumsi serat ratarata sebesar $25 \mathrm{~g} / \mathrm{hr}$ dianggap cukup untuk memelihara kesehatan tubuh. Selanjutnya menurut Sediaoetama (1999), serat bahan makanan dapat berperan terhadap pengikatan asam empedu yang diduga sebagai promotor terbentuknya proses (kimiawi) karsinogenesis, sehingga apabila proses pengikatan itu terjadi dapat menurunkan risiko terjadinya kanker usus besar, dan juga dapat menurunkan kadar kolesterol darah.

Dari Gambar 11 terlihat bahwa semakin banyak ikan dan rumput laut yang ditambahkan semakin besar kadar serat kasarnya. Hal ini juga dinyatakan oleh Wirjatmadi et al. (2002), bahwa serat kasar meningkat seiring dengan penambahan proporsi rumput laut pada mie rumput laut. Menurut Datu et al. (2002), kebutuhan serat bagi anak dihitung berdasarkan usia. Pada orang dewasa, kebutuhan serat dalam sehari berkisar antara 25-35 g per hari. Untuk anak-anak dapat diberikan sebanyak: usia anak (tahun) + $5 \mathrm{~g}$. Karena kandungan serat tertinggi pada mie ikan-rumput laut hanya $0,77 \%$ maka anak usia 1 tahun pun sudah dapat

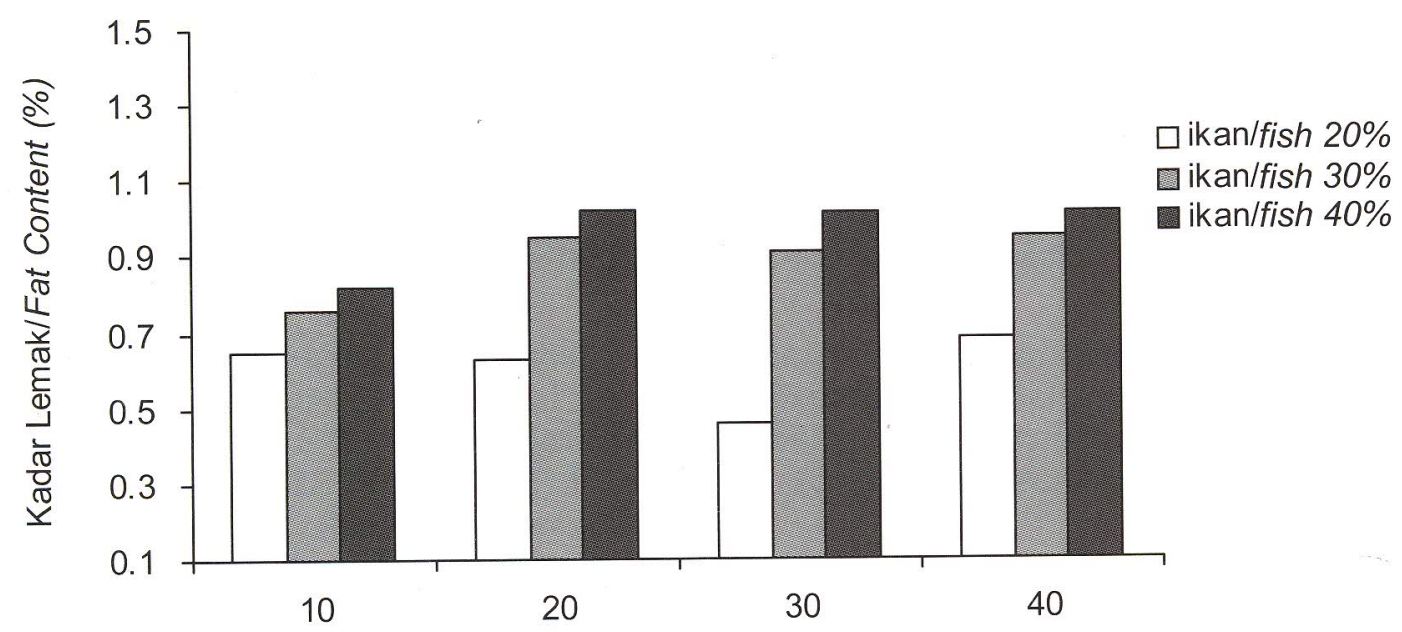

Rumput Laut/Seaweed (\%)

Gambar 10. Kadar lemak mie ikan-rumput laut dari beberapa perlakuan. Figure 10. Fat content of fish-seaweed noodle from various treatments. 


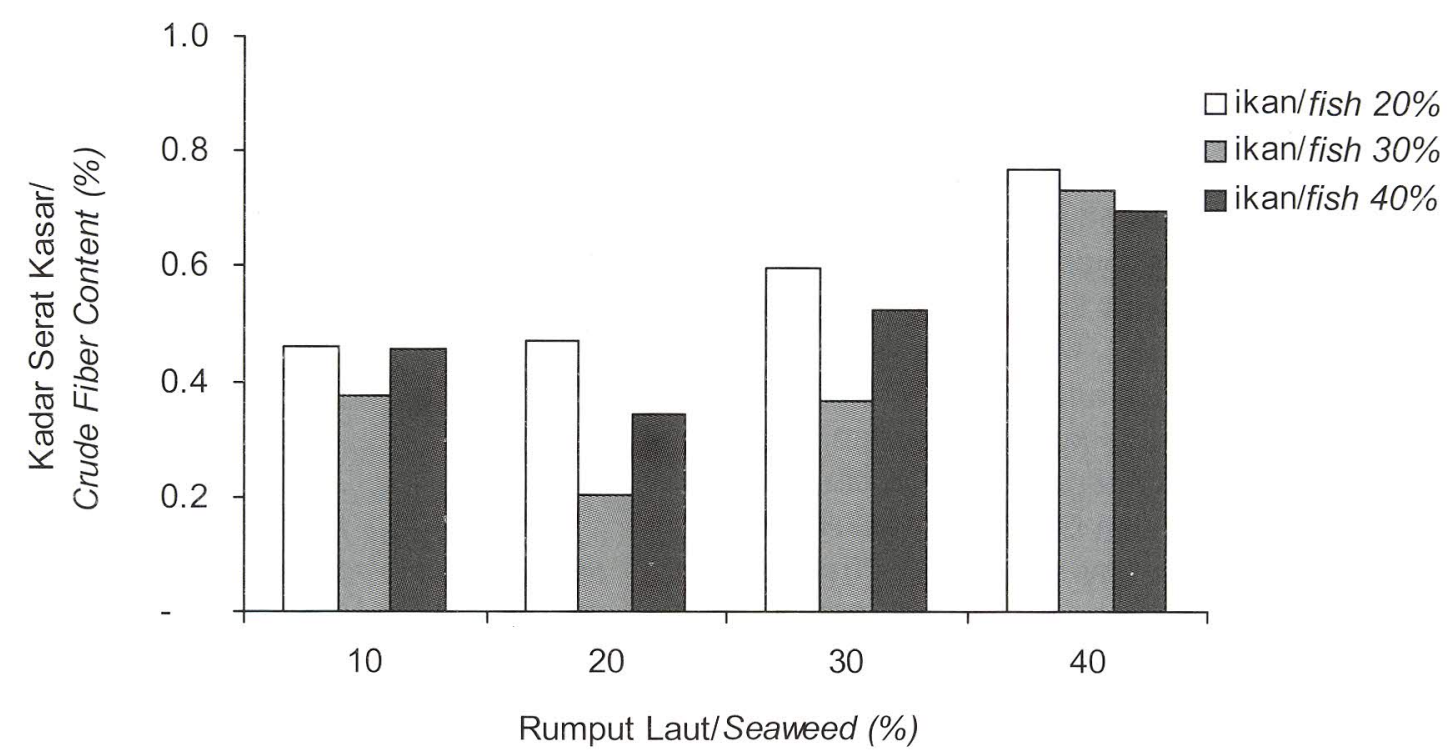

Gambar 11. Kadar serat kasar mie ikan-rumput laut dari beberapa perlakuan. Figure 11. Crude fiber content of fish- seaweed noodle from various treatments.

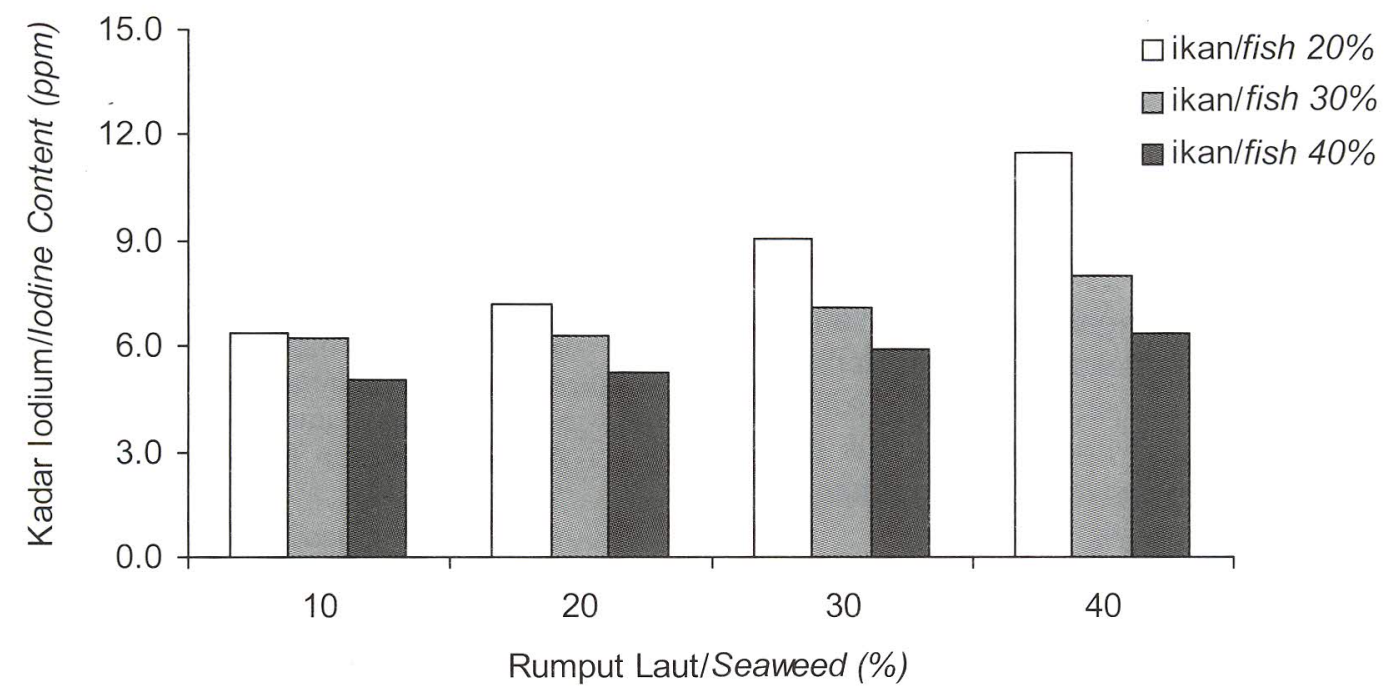

Gambar 12. Kadar iodium mie ikan-rumput laut dari beberapa perlakuan. Figure12. lodine content of fish-seaweed noodle from various treatments.

mengkonsumsi mie kering campuran ikan dan rumput laut ini. Menurut Suryaalamsah (2007), penambahan bubur rumput laut $E$. cottonii sebanyak $37 \%$ ke dalam bahan dasar mie basah, mie instan, dan mie kering, bisa meningkatkan total serat pangan hingga $29,7 \%$ berat kering (mie basah), 18,2\% berat kering (mie instan) dan 18,8\% berat kering (mie kering). Untuk memenuhi asupan serat pangan $30 \mathrm{~g} / \mathrm{hr}$ hari, Suryaalamsah (2007) menganjurkan orang dewasa mengkonsumsi $48 \mathrm{~g}$ mie basah, atau $28 \mathrm{~g}$ mie instan, atau $27 \mathrm{~g}$ mie kering yang mengandung rumput laut per hari dalam menu makan. la menganjurkan anakanak mengkonsumsi $32 \mathrm{~g}$ mie basah, $19 \mathrm{~g}$ mie instan, dan $18 \mathrm{~g}$ mie kering yang mengandung rumput laut per hari untuk memenuhi kecukupan iodium dalam menu makanannya.

\section{lodium}

Pada Gambar 12 dapat dilihat bahwa kadar iodium terendah terdapat pada perlakuan penambahan ikan 
$40 \%$ dan rumput laut $10 \%$ yaitu sebanyak $5,07 \mathrm{ppm}$ dan tertinggi pada perlakuan penambahan ikan $20 \%$ dan rumput laut $40 \%$ sebanyak $11,5 \mathrm{ppm}$. Menurut Wirjatmadi et al. (2002), produk mie dengan penambahan rumput laut sebesar $30 \%$ mengandung kadar iodium sebanyak 156,89 $\mathrm{\mu g}$ per $100 \mathrm{~g}$ sampel. Mengkonsumsi $30 \mathrm{~g}$ mie yang mengandung rumput laut akan meningkatkan kadar iodium sebanyak $119 \mu \mathrm{g}$ (Tobias et al., 2005). Menurut Almatsier (2001), konsumsi normal iodium adalah 100-150 $\mu \mathrm{g}$ sehari atau sekitar 1-2 $\mu \mathrm{g}$ per $\mathrm{kg}$ bobot badan. Dalam Widyakarya Nasional Pangan dan Gizi dinyatakan bahwa Angka Kecukupan Gizi (AKG) untuk iodium adalah sebagai berikut: bayi sebesar $50-70 \mu \mathrm{g}$, balita dan anak sekolah sebesar 70-120 $\mu \mathrm{g}$, remaja dan dewasa $150 \mu \mathrm{g}$, ibu hamil ditambah $25 \mu \mathrm{g}$ dan ibu menyusui ditambah $50 \mu \mathrm{g}$ per hari (Anon., 1998).

Hasil analisis statistik mie ikan-rumput laut menunjukkan bahwa perlakuan penambahan ikan dan rumput laut berpengaruh terhadap kadar iodium $(p<0,05)$. Menurut Suryaalamsah (2007), penambahan bubur rumput laut $37 \%$ akan meningkatkan $5,2 \mathrm{ppm}$ bobot kering iodium dalam mie basah; $5,5 \mathrm{ppm}$ bobot kering iodium dalam mie instan; dan $6 \mathrm{ppm}$ bobot kering iodium dalam mie kering. Komposisi mie tanpa ikan dan rumput laut mempunyai kadar iodium $0 \%$ (perlakuan kontrol).

\section{KESIMPULAN}

- Dari hasil analisis organoleptik untuk kenampakan, warna, aroma dan tekstur, nilai yang terbaik adalah perlakuan mie dengan penambahan ikan 30\% dan rumput laut $20 \%$, sedangkan untuk rasa yang terbaik adalah perlakuan penambahan ikan $30 \%$ dan rumput laut $10 \%$.

- Hasil analisis statistik menunjukkan bahwa penambahan ikan dan rumput laut berpengaruh terhadap kadar protein dan iodium, sedangkan untuk serat kasar penambahan ikan tidak berpengaruh tetapi penambahan rumput laut berpengaruh

- Berdasarkan pertimbangan peningkatan kadar protein, iodium, dan serat kasar serta karakteristik organoleptik, pada pembuatan mie kering dapat ditambahkan ikan sebanyak $30 \%$ dan rumput laut $20 \%$.

\section{UCAPAN TERIMA KASIH}

Ucapan terima kasih disampaikan kepada Saudari Netty Sri Wulandari yang telah membantu kegiatan penelitian ini hingga selesai.

\section{DAFTAR PUSTAKA}

AOAC. 2000. Official Methods of Analysis. Association of Official Analytical Chemist. EUA.

Almatsier, S. 2001. Prinsip Dasar IImu Gizi. PT. Gramedia Pustaka Utama. Jakarta. p.85-87.

Anonim. 1998. Widya Karya Nasional Pangan dan Gizi VI. Serpong, Jakarta.

Anonim. 2007. Macam-macam tepung. http:// www.plnntt.co.id/forum/archive/index.php/t 6023. html. Diakses pada tanggal 2 Februari 2008.

Anonymous. 2008a. Ebookpangan.com. Diakses pada tanggal 12 Januari 2009.

Anonim. 2008b. Teknologi pembuatan mie skala industri rumah tangga. http://www. kamusilmiah.com/ teknologi/teknologi-pembuatan-mie-skala-industrirumah-tangga/. Diakses pada tanggal 9 Agustus 2009.

Anonymous. 2009. Produksi Perikanan Tangkap Indonesia, 2008. Direktorat Jenderal Perikanan Tangkap. Departemen Kelautan dan Perikanan. 9(1).

BSN. 1992. SNI-01-2891-1992. Mi kering. Badan Standardisasi Nasional, Jakarta. p. 1-3.

BSN. 2000. SNI-01-3551-2000. Syarat Mutu Mie Kering Berdasarkan SNI Mie kering. Badan Standardisasi Nasional, Jakarta. p. 1-3.

Chang, H.C. and Wu, L.C. 2008. Texture and quality properties of chinese fresh egg noodles formulated with green seaweed (Monostroma nitidum) powder. Journal of Food Science. 73(8): 398-404.

Datu, D.Y.R., Bilang, M., dan Amrullah, S.D. 2002. Mempelajari pengolahan mie dari campuran tepung sagu dan tepung jagung. Teknologi Hasil Pertanian Universitas Hasanuddin. www.unhas.ac.id/tekpert. Diakses pada tanggal 23 Mei 2009.

Garrow, J.S. and James, W.P.T. 1993. Carbohydrate. Human Nutrition and Dietetics. Churchill Livingstone, Edinburgh London, Madrid, Melbourne, New York and Tokyo. p. 62-71.

Irianto, H.I. dan Soesilo, I. 2007. Dukungan Teknologi Penyediaan Produk Perikanan. Makalah disampaikan pada Seminar Nasional Hari Pangan sedunia 2007, Bogor. p. 13-20.

Riyanto. 2004. Optimasi metode penentuan kandungan iodium dalam garam dapur dengan spektrofotometer UV-VIS.LOGIKA. 1(2): 31-37. Fakultas Matematika dan IImu Pengetahuan Alam Universitas Islam Indonesia.

Sediaoetama, A.D. 1999. IImu Gizi untuk Mahasiswa dan Profesi Jilid II. Dian Rakyat, Jakarta.

Suryaalamsah, I. 2007. Mie kaya iodium dan serat setelah ditambahkan rumput laut. http:// www.pustakatani.org/Hasil Penelitian/tabid/55/ctl/ ArticleView/mi d/375/articleld/234/Mie Kaya lodium dan Serat Setelah Ditambahkan Rumput Laut.aspx. Diakses pada tanggal 8 Februari 2008.

Tobias, J.R., Labartine, E.C., Gustilo, E.A.M., Quindara, C.S., and Cabagbag, M.C. 2005. Development of Instant Spaghetti with Seaweeds. p. 1-4. 
Winarno, F.G., Fardiaz, S., dan Fardiaz, D. 1992. Kimia Pangan Gizi. Gramedia Pustaka Utama, Jakarta.

Winarno, F.G., Fardiaz, S., dan Fardiaz, D. 1996 Teknologi Pengolahan Rumput Laut. Pustaka Sinar Harapan, Jakarta. p. 1- 15.
Wirjatmadi, B., Adriani, M., dan Purwanti, S. 2002. Pemanfaatan rumput laut (Eucheuma cottonii) dalam meningkatkan nilai kandungan serat dan iodium dalam pembuatan mi basah. J. Penel. Medika Eksakta. 3(1): 89-104. 
